\title{
Case Study: Database Management for Solid Waste Management Services
}

\author{
Tuangthong Patcharaprutipakorn, Direk Thongaraim, and Nujcha Thatreenaranon
}

\begin{abstract}
Due to the development of the local administration and information technology as well as no direction And environmental issues need to be resolved urgently. This includes waste problems and wastewater they need to get the right deal. This research aims to develop management systems, databases and GIS to analyze the proper management of solid waste and wastewater treatment in the local government. This research has developed selection criteria for solid waste management and waste water treatment. The above items are considered to be sensitive to the weight factor and provide the appropriate level of 3 sub-specialists from environmental factors. The results of the development consist of five elements, including geological, economic, social, communication and the density. Assessment has use of database management systems solid waste and waste water. The ability to work with an average of 4.21 is shows that the system has the ability to use it in the most.
\end{abstract}

Index Terms-Solid waste management, waste, wat pruranawas.

\section{INTRODUCTION}

Bangkok want the community in Bangkok have application of information and communications technology to assist in the operation, management and distribution of information to the public in order to optimize the mission work. An integrated and unified information system. Reduce duplication of work. The public service is fast, transparent audit community in Bangkok because of the lack of personal with the knowledge of information technology. The development is a directionless and lacks continuity.

Bangkok's Solid Waste Management Plan 2558-2562 to Bangkok to be a waste of resources, is environmentally friendly. A framework for the work of the various agencies to achieve the goal. Bangkok is a city of green Lifestyle and environment-friendly society, a society of Learning and Wellbeing and the growing awareness of global environmental issues. Bangkok is the center of the region's needs Equal leading industrialized city with a good environment and a sustainable metropolis [1]. The development goals (Gold) Bangkok as a regional hub of transportation communication, center of education, culture and health, a regional center of economic science, Business, finance and health as a green metropolis. A way of life and society that is friendly to the environment and society to learn the well-being, but in the mid of economic expansion and population increase due to the growth of cities affects environmental quality city. Degradation of natural resources

Manuscript received February 5, 2017; revised April 19, 2017.

The authors are with the Bangkokthonburi University, Thailand (e-mail: boath@hotmail.com). is increasing problem of waste. The researchers recruited Wat Pruranawas's community Thawi Wattana up to be a model community in the management of solid waste services. developed the best solutions to the problem of collection/transport of SW in Alexandria, Egypt. Apaydin and Gonullu [2].

\section{A. The Framework of the System}

The research began with the development of criteria to select areas for solid waste management and wastewater by collecting data from research papers related and environmental experts. Then, researcher has developing database management systems, data collection systems from community in Thawi Wattana, Bangkok and environmental experts. We lead the development and outcome measures appropriate areas for solid waste management system, from the database to use GIS to selected areas of solid waste management and wastewater treatment. The system was developed to test the staff of Public Health and Environment, Thawi Wattana, Bangkok.

\section{B. Develop Criteria to Select Areas for Solid Waste Management.}

The objectives of this research project are to get a better understanding of the solid waste management system in Banklang municipality. By Assistant Professor Dr. Raywadee Roachanakanan and Team

The local administration is a key person who should give higher priority to environmental problems. Strategic planning on solid waste management involving public participation and cooperation among stakeholders should be setup [3].

DEA to calculate the waste collection cost efficiency in the Flemish municipalities. In addition to the focus of preceding studies, they also studied related demographic information, such as age composition of the population, political preferences, income etc.[ 4]. Had previously used the same dataset to investigate the influence of policies (such as weekly instead of biweekly collections, municipal joint ventures, and policies that aim to reduce waste generation) [5].

Another application of DEA on Spanish waste collection was conducted by Garcia-Sanchez [6].

\section{METHOD}

In the research start from develop the criterion to choose the area by collecting the data from Wat pruranawas community and specialist. The database management system will told the process to scope the suitable area for waste management service this system sent the data and test by 
sanitary officer and environmental specialist

Questionnaire is divided into three parts:

One: for the development of criteria to select the area of solid waste management. The Criteria to be considered is divided into five areas: geology, economic, social, transportation and density.

Second: recommendation is a more open-ended question. The results of the development of the criteria listed in Table I to 5 .

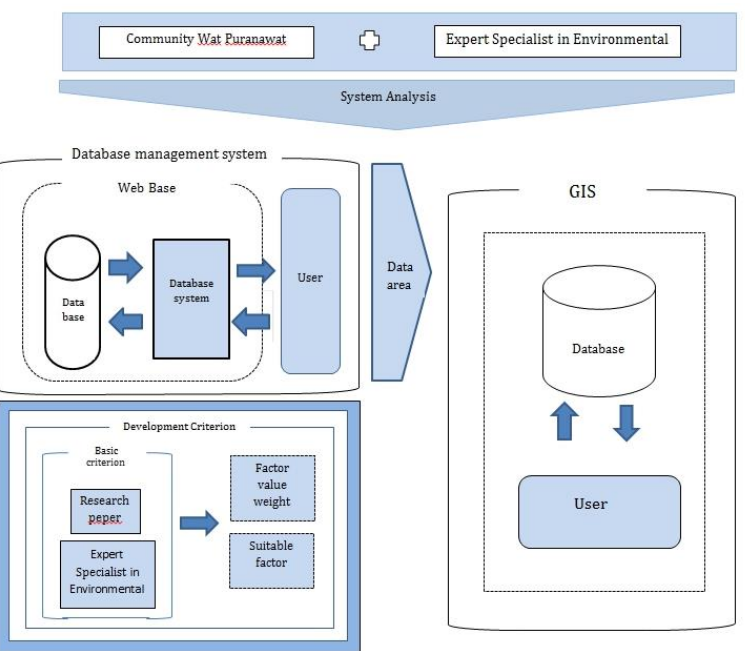

Fig. 1. Questionnaire is divided into three parts.

TABLE I: GEOLOGY SELECTION CRITERIA FOR SOLID WASTE

\begin{tabular}{|c|c|c|c|c|}
\hline \multicolumn{5}{|c|}{ MANAGEMENT } \\
\hline \multicolumn{5}{|c|}{ Geology } \\
\hline \multirow{3}{*}{ Factor } & \multicolumn{4}{|c|}{ Selection Criteria } \\
\hline & \multicolumn{2}{|c|}{ Garbage } & \multicolumn{2}{|c|}{$\begin{array}{c}\text { Wastewater } \\
\text { treatment }\end{array}$} \\
\hline & value* & value $* *$ & value* & value** \\
\hline The type of soil & 4.33 & - & 3.67 & - \\
\hline 1) Stone & - & 2.00 & - & 2.00 \\
\hline 2) Sandy soil & - & 1.67 & - & 2.00 \\
\hline 3) Loose soil & - & 4.00 & - & 3.33 \\
\hline 4) Clay & - & 5.00 & - & 4.33 \\
\hline 5) Lateritic soil & - & 3.00 & - & 2.67 \\
\hline $\begin{array}{l}\text { The elevation of the } \\
\text { area }\end{array}$ & 4.00 & - & 4.33 & - \\
\hline $\begin{array}{l}\text { 1) Less than } 300 \\
\text { meters }\end{array}$ & - & 3.50 & - & 3.00 \\
\hline 2) $301-600$ meters & - & 1.50 & - & 2.50 \\
\hline 3) $601-900$ meters & - & 2.00 & - & 2.50 \\
\hline 4) $901-1,200$ meters & - & 2.00 & - & 2.00 \\
\hline $\begin{array}{l}\text { 5) Higher than } 1,200 \\
\text { meters }\end{array}$ & - & 1.00 & - & 1.00 \\
\hline $\begin{array}{l}\text { Distance from } \\
\text { natural water source }\end{array}$ & 4.67 & - & 4.67 & - \\
\hline $\begin{array}{l}\text { 1) Less than } 300 \\
\text { meters }\end{array}$ & - & 0.33 & - & 2.33 \\
\hline 2) 301-600 meters & - & 1.67 & - & 2.67 \\
\hline 3) $601-900$ meters & - & 2.67 & - & 4.00 \\
\hline 4) $901-1,200$ meters & - & 4.33 & - & 3.67 \\
\hline $\begin{array}{l}\text { 5) Higher than } 1,200 \\
\text { meters }\end{array}$ & - & 4.67 & - & 2.33 \\
\hline
\end{tabular}

TABLE II: ECONOMY SELECTION CRITERIA FOR SOLID WASTE MANAGEMENT

\begin{tabular}{|c|c|c|c|c|}
\hline \multicolumn{5}{|c|}{ Economy } \\
\hline \multirow[t]{3}{*}{ Factor } & \multicolumn{4}{|c|}{ Selection Criteria } \\
\hline & \multicolumn{2}{|c|}{ Garbage } & \multicolumn{2}{|c|}{$\begin{array}{c}\text { Wastewater } \\
\text { treatment }\end{array}$} \\
\hline & value* & value** & value* & value $^{* * *}$ \\
\hline Land utilization & 4.33 & - & 4.67 & - \\
\hline
\end{tabular}

\begin{tabular}{lcccc}
\hline 1) Wilderness & - & 5.00 & - & 5.00 \\
2) agriculture & - & 3.67 & - & 3.33 \\
3) Less dense & - & 4.00 & - & 3.67 \\
communities & & 3.33 & - & 3.33 \\
4) Medium community & - & -67 & - & 2.33 \\
5) Dense community / & - & 2.67 \\
commercial. & & & & \\
\hline land prices & $\mathbf{4 . 0 0}$ & - & $\mathbf{4 . 3 3}$ & - \\
1) The land was & - & 5.00 & - & 5.00 \\
donated by the public. & & & & \\
2) $100 \%$ lower price & - & 3.67 & - & 4.33 \\
than the appraised value. & & 2.67 & - & 3.67 \\
3) Price greater than or & - & & & \\
less than the appraised & & & & 1.67 \\
value of $100 \%$. & - & 1.67 & - & \\
4) $100-200 \%$ higher \\
than the appraised value.
\end{tabular}

Note: Value* $=$ The weight factor, Value ${ }^{* *}=$ The suitability of the sub factor

TABLE III: SOCIETY SELECTION CRITERIA FOR SOLID WASTE MANAGEMENT

\begin{tabular}{|c|c|c|c|c|}
\hline \multicolumn{5}{|c|}{ Society } \\
\hline \multirow[t]{3}{*}{ Factor } & \multicolumn{4}{|c|}{ Selection Criteria } \\
\hline & \multicolumn{2}{|c|}{ Garbage } & \multicolumn{2}{|c|}{$\begin{array}{c}\text { Wastewater } \\
\text { treatment }\end{array}$} \\
\hline & value* & value*** & value* & value*** \\
\hline $\begin{array}{l}\text { The distance from the } \\
\text { ruins }\end{array}$ & 4.67 & - & 3.67 & - \\
\hline 1) Less than $1 \mathrm{~km}$ & - & 0.67 & - & 0.67 \\
\hline 2) $1-2 \mathrm{~km}$ & - & 2.00 & - & 1.00 \\
\hline 3) $2-3 \mathrm{~km}$ & - & 2.67 & - & 2.67 \\
\hline 4) $3-4 \mathrm{~km}$ & - & 3.33 & - & 3.00 \\
\hline 5) $4-5 \mathrm{~km}$ & - & 4.00 & - & 4.00 \\
\hline 6) $5-6 \mathrm{~km}$ & - & 3.67 & - & 3.67 \\
\hline 7) $6-7 \mathrm{~km}$ & - & 4.00 & - & 3.67 \\
\hline 8) $7-8 \mathrm{~km}$ & - & 4.00 & - & 3.67 \\
\hline 9) $8-9 \mathrm{~km}$ & - & 4.00 & - & 3.00 \\
\hline 10) $9-10 \mathrm{~km}$ & - & 4.33 & - & 3.00 \\
\hline 11) More than $10 \mathrm{~km}$ & - & 4.00 & - & 2.67 \\
\hline $\begin{array}{l}\text { The distance from the } \\
\text { community }\end{array}$ & 4.33 & - & 4.67 & - \\
\hline 1) Lower than 500 meter & - & 1.00 & - & 1.67 \\
\hline 2) $501-1000$ meter & - & 1.67 & - & 2.67 \\
\hline 3) $1,001-1,500$ meter & - & 3.00 & - & 4.67 \\
\hline 4) $1,501-2,000$ meter & - & 4.33 & - & 4.00 \\
\hline
\end{tabular}




\begin{tabular}{lcccc}
\hline 5) More than 2,000 meter & - & 5.00 & - & 2.67 \\
\hline Distance from main road & 4.00 & - & 4.33 & - \\
1) Lower than 300 meter & - & 1.33 & - & 2.00 \\
2) 301-600 meter & - & 2.67 & - & 3.33 \\
3) 601-900 meter & - & 3.67 & - & 3.67 \\
4) 901-1,200 meter & - & 4.33 & - & 3.33 \\
5) More than 1,200 meter & - & 3.67 & - & 2.67 \\
\hline
\end{tabular}

Note: Value* $=$ The weight factor, Value ${ }^{* *}=$ The suitability of the sub factor

TABLE IV: TRANSPORTATION SELECTION CRITERIA FOR SOLID WASTE MANAGEMENT

\begin{tabular}{|c|c|c|c|c|}
\hline \multicolumn{5}{|c|}{ Transportation } \\
\hline \multirow[t]{3}{*}{ Factor } & \multicolumn{4}{|c|}{ Selection Criteria } \\
\hline & \multicolumn{2}{|c|}{ Garbage } & \multicolumn{2}{|c|}{$\begin{array}{c}\text { Wastewater } \\
\text { treatment }\end{array}$} \\
\hline & value* & value** & value* & value** \\
\hline Transportation & 4.33 & - & 3.33 & - \\
\hline $\begin{array}{l}\text { 1) Away from the } \\
\text { communities up to } 1 \mathrm{~km} \\
\text { and a road cut through. }\end{array}$ & - & 1.00 & - & 3.33 \\
\hline $\begin{array}{l}\text { 2) Away from the } \\
\text { communities up to } 2 \mathrm{~km} \\
\text { and a road cut through. }\end{array}$ & - & 1.67 & - & 3.00 \\
\hline $\begin{array}{l}\text { 3) Away from the } \\
\text { communities up to } 3 \mathrm{~km} \\
\text { and a road cut through. }\end{array}$ & - & 2.33 & - & 2.33 \\
\hline $\begin{array}{l}\text { 4) Away from the } \\
\text { communities up to } 4 \mathrm{~km} \\
\text { and a road cut through. }\end{array}$ & - & 2.67 & - & 2.33 \\
\hline $\begin{array}{l}\text { 5) Away from the } \\
\text { communities up to } 5 \mathrm{~km} \\
\text { and a road cut through. }\end{array}$ & - & 3.33 & - & 2.33 \\
\hline $\begin{array}{l}\text { 6) Away from the } \\
\text { communities up to } 6 \mathrm{~km} \\
\text { and a road cut through. }\end{array}$ & - & 3.33 & - & 1.67 \\
\hline $\begin{array}{l}\text { 7) Away from the } \\
\text { communities up to } 7 \mathrm{~km} \\
\text { and a road cut through. }\end{array}$ & - & 3.67 & - & 1.33 \\
\hline $\begin{array}{l}8 \text { Away from the } \\
\text { communities up to } 8 \mathrm{~km} \\
\text { and a road cut through. }\end{array}$ & - & 3.00 & - & 0.67 \\
\hline $\begin{array}{l}\text { 9) Away from the } \\
\text { communities up to } 9 \mathrm{~km} \\
\text { and a road cut through. }\end{array}$ & - & 2.33 & - & 0.67 \\
\hline $\begin{array}{l}\text { 10) Away from the } \\
\text { communities up to } 10 \\
\mathrm{~km} \text { and a road cut } \\
\text { through. }\end{array}$ & - & 2.67 & - & 0.67 \\
\hline $\begin{array}{l}\text { 11) Community far } \\
\text { more than } 10 \mathrm{~km} \text { and a } \\
\text { road cut through. }\end{array}$ & - & 1.67 & - & 0.33 \\
\hline
\end{tabular}

TABLE V: DENSITY SELECTION CRITERIA FOR SOLID WASTE MANAGEMENT Density

\begin{tabular}{lcccc}
\hline \multicolumn{1}{c}{ Factor } & \multicolumn{3}{c}{ Selection Criteria } \\
\cline { 2 - 5 } & \multicolumn{3}{c}{ Garbage } & \multicolumn{2}{c}{$\begin{array}{l}\text { Wastewater } \\
\text { treatment }\end{array}$} \\
\cline { 2 - 5 } & value* & value*** & value* & value** \\
\hline $\begin{array}{l}\text { Suitable to accommodate } \\
\text { the increased volume in the } \\
\text { future. }\end{array}$ & 5.00 & - & 4.67 & - \\
$\begin{array}{l}\text { 1) Capacity increases in } \\
\text { the 10 years future. } \\
\text { 2) Capacity increases in }\end{array}$ & - & 3.00 & - & 4.00 \\
\hline
\end{tabular}

\begin{tabular}{|c|c|c|c|c|}
\hline $\begin{array}{l}\text { the } 20 \text { years future. } \\
\text { 3) Capacity increases in } \\
\text { the } 30 \text { years future. }\end{array}$ & - & 4.00 & - & 3.33 \\
\hline The suitability of factory & 3.67 & - & 4.00 & - \\
\hline $\begin{array}{l}\text { 1) Capacity increases in } \\
\text { the } 10 \text { years future. }\end{array}$ & - & 2.67 & - & 3.33 \\
\hline $\begin{array}{l}\text { 2) Capacity increases in } \\
\text { the } 20 \text { years future. }\end{array}$ & - & 3.67 & - & 4.33 \\
\hline $\begin{array}{l}\text { 3) Capacity increases in } \\
\text { the } 30 \text { years future. }\end{array}$ & - & 3.33 & - & 3.33 \\
\hline $\begin{array}{l}\text { Appropriate to the } \\
\text { population }\end{array}$ & 4.67 & - & 5.00 & - \\
\hline $\begin{array}{l}\text { 1) Capacity increases in } \\
\text { the } 10 \text { years future. }\end{array}$ & - & 3.33 & - & 4.00 \\
\hline $\begin{array}{l}\text { 2) Capacity increases in } \\
\text { the } 20 \text { years future. }\end{array}$ & - & 4.67 & - & 4.67 \\
\hline $\begin{array}{l}\text { 3) Capacity increases in } \\
\text { the } 30 \text { years future. }\end{array}$ & - & 4.00 & - & 3.33 \\
\hline
\end{tabular}

\section{A. Development System}

Database management systems, solid waste and waste water in local government developed with PHP and using MySQL to create a database. It has collected data on solid waste management and environmental experts and related documents. The data were analyzed system design and development.

The system consists of

1) Solid waste management, including the management information area for proper solid waste management information management of household waste / established of data management and disposal of garbage in various forms.

2) Waste water management, including the area suitable for wastewater management information wastewater effluent of households / establishments, and management of wastewater treatment.

3) The report shows the amount of solid waste, including reports showing waste storage operation, Report Solid Waste Forecast and Trends report shows the amount of solid waste that is expected to happen in the future.

The ability to Evaluate to use the system are test by staff in public health and the environment and community staff at Thawi wattana, Bangkok. The tools used to collect information, including interviews and questionnaires are detailed below.

The interview is an open-ended question. Questions will look on Problems encountered by applications and what is to improve

Questionnaire consists of two parts: one for user data by a closed-ended questions and a open-ended questions. The second usage information system consists of a database management system. The classification criteria are accessing the ability to operate the system into five areas consist of: Efficiency, effectiveness, Satisfaction, Reliability and Learnability. Descriptive Method is use by Mean and standard deviation

Accessment of the work consists of two parts: Accessment of the use of the solid waste management system database. Details are in Table VI.

The results of this accessment can be used for solid waste management system database. The results were as follows:

Its overall performance is at the highest level $(\overline{\mathbf{x}}=4.22$, 
S.D. $=0.39$ ), indicating that the user can use the system to achieve the goals set value and integrity. Both input the report is an overview of the system is easy and convenient to use.

TABLE VI: ASSESSMENT OF THE ABILITY TO USE A DATABASE MANAGEMENT SYSTEM FOR SOLID WASTE

\begin{tabular}{|c|c|c|c|}
\hline Operating System & $\overline{\mathbf{x}}$ & S.D. & Level \\
\hline \multicolumn{4}{|l|}{ The Efficiency } \\
\hline can enter more easily managed. & 4.33 & 0.58 & Max \\
\hline can view various reports easily. & 4.33 & 0.58 & Max \\
\hline The overall system is convenient and easy to use. & 4.00 & 0.00 & Most \\
\hline Mean & 4.22 & 0.39 & Max \\
\hline \multicolumn{4}{|l|}{ The effectiveness } \\
\hline $\begin{array}{l}\text { The system is divided into categories of } \\
\text { information appropriately. }\end{array}$ & 4.33 & 0.58 & Max \\
\hline $\begin{array}{l}\text { The language used is appropriate, clear, accurate, } \\
\text { easily to understood. }\end{array}$ & 4.33 & 0.58 & Max \\
\hline $\begin{array}{l}\text { he process from start to finish makes it easy to } \\
\text { use. }\end{array}$ & 4.00 & 0.00 & Most \\
\hline $\begin{array}{l}\text { The order process is consistent with the overall } \\
\text { ease of use. }\end{array}$ & 4.33 & 0.58 & Max \\
\hline Mean & 4.25 & 0.44 & Max \\
\hline \multicolumn{4}{|l|}{ Satisfaction } \\
\hline Colors of the system is appropriate & 4.33 & 0.58 & Max \\
\hline The font size is appropriate. & 3.67 & 0.58 & Most \\
\hline The buttons or messages are appropriate. & 4.67 & 0.58 & Max \\
\hline The format of the system is beautiful. & 3.67 & 0.58 & Most \\
\hline The format of the system is clean. & 4.00 & 0.00 & Most \\
\hline Mean & 4.07 & 0.47 & Most \\
\hline \multicolumn{4}{|l|}{ The reliability of use. } \\
\hline $\begin{array}{l}\text { The system can display the results of their data } \\
\text { accurately and completely filled. }\end{array}$ & 4.33 & 0.58 & $\operatorname{Max}$ \\
\hline $\begin{array}{l}\text { The system can report the correct information to } \\
\text { when fill. }\end{array}$ & 4.33 & 0.58 & Max \\
\hline The system can be used in practice. & 4.33 & 0.58 & Max \\
\hline Mean & 4.33 & 0.58 & Max \\
\hline \multicolumn{4}{|l|}{ The ability to learn. } \\
\hline $\begin{array}{l}\text { Understand a working model of the overall } \\
\text { system as well. }\end{array}$ & 4.00 & 0.00 & Most \\
\hline \multirow[t]{2}{*}{ Learn how to use it quickly. } & 4.33 & 0.58 & Max \\
\hline & 4.17 & 0.29 & Most \\
\hline
\end{tabular}

The effectiveness Overall, the highest level ( $\overline{\mathbf{x}}=4.25$, S.D. $=0.44)$, indicating that the user can work accomplished by the work place. The system is putting the proper language category, number of steps and the order process is appropriate making it easier to use.

Satisfaction Overall, the high level $(\overline{\mathbf{x}}=4.07$, S.D. $=0.47)$, indicating that the user is satisfied with the various forms of both colors. The buttons or a different font size and style system is beautiful and clearly.

The reliability of applications by combining the highest level $(\overline{\mathbf{x}}=4.33$, S.D. $=0.58)$, indicating that the system is working properly, Results from both the fill, Reports from the system and the idea that the system can be used to real perform.

The ability to learn by combining the high level $(\overline{\mathrm{x}}=4.17$, S.D. $=0.29$ ), indicating that the user can learn the system quickly and understand the overall functioning of the system as well.

\section{CONCLUSION}

The development of criteria can be summarized as five elements as follow:

Geology: 5 types of soil, elevation of the area 5 item and distance of the water resource 5 item.

Economy: 5 types of land use, 5 types of land price and Distance from water main 11 items.

Social: distance of zone remain 11 items, distance of the community 5 item, distance of roadcut through 5 item.

Density: Suitable to accommodate the increased volume in the future 3 item, Suitable plants 3 item and Appropriate to the population 3 items.

The results of the research led to the development of the sub-factors with the highest average of all key factors to the development of GIS for select in the area of solid waste management and wastewater treatment further.

The development of the database management system is collect data for the development of environmental experts and officials from the Health and Environment Committee and community Thawi Watthana. The system consists of four main components:

1) Solid waste management is the management for all solid waste.

2) Waste water management is the management for all waste water.

3) The report shows solid waste as solid waste data for a report showing all users in the fields of solid waste management.

4) The report shows that the report shows data for all water users fill in the waste water management. GIS is use for selected areas of solid waste management and wastewater treatment. Systems based on the guidelines from the development of criteria and outcome measures for the proper management of solid waste management system database.

When the development is completed, the researchers studied the ability to use the system to test the system with the Thawi Watthana community board and the public in Wat Pruranawas Thawi Watthana, Bangkok. The study found that the database management system, what are the strengths of the system is effective, effectiveness and reliable in use. The system shows the user a reliable system that can be used in practice. In addition, users can use the system correctly and the achievement of set goals met.

\section{REFERENCES}

[1] Bangkok Environment, Bangkok's Solid Waste Management Plan 2558-2562, 2015.

[2] A. Moustafa, A. A. Abdelhalim, A. B. Eltawil, and N. Fors, "Waste collection vehicle routing problem: case study in Alexandria, Egypt," in Proc. the 19th International Conference on Industrial Engineering and Engineering Management, pp. 935-944, October 2012.

[3] R. Roachanakanan, "The objectives of this research project are to get a better understanding of the solid waste management system in Banklang municipality," 2011.

[4] N. Rogge and S. Jaeger, "Measuring and explaining the cost efficiency of municipal solid waste collection and processing services," Omega, vol. 41, no. 4, pp. 653-664, Aug. 2013.

[5] S. Jaeger, J. Eyckmans, N. Rogge, and T. Puyenbroeck, "Wasteful waste-reducing policies? The impact of waste reduction policy instruments on collection and processing costs of municipal solid waste." Waste Management, New York, N.Y., vol. 31, no. 7, pp. 1429-40, Jul. 2011.

[6] I. Garcia-Sanchez, "The performance of Spanish solid waste collection," Waste Management \& Research, vol. 26, no. 4, pp. 327-336, Aug. 2008. 


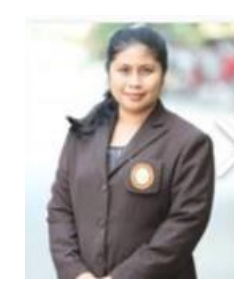

Tuangthong Patcharaprutipakorn was born in Thailand in 1978. She got the M.S. Rungsit University, Pathumthani, Thailand, 2004; the B.B.A. Dhurakij Pundit University, Bangkok, Thailand, 2000.

She worked as SA Fujitsu (Thailand) (2004), senior engineer Fujitsu (Thailand) (2005-2006), lecturer, Faculty of Science, Information Technology, Bangkokthonburi University (2007-Present)

Mrs. Tuangthong Patcharaprutipakorn has a memberships in Societies: Prof. Dr. Chidchanok Lursinsap, Prof. Dr. Jongjit Hirunlabh and Prof, Dr. Chaiyong Promwong.

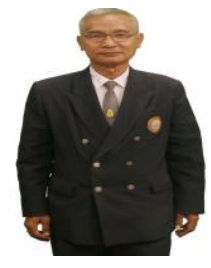

Direk Tongaram was born in Thailand in 1947. He got the B.S.A. Agronomy University of Eastern Philippines, Philippiness, 1973; the M.S.c. Horticulture Central Luzon State University, Philippines, 1975; the M.Eng. irrigation engineering, Katholieke Univeristeit Leuven, Belgium, 1989

He worked as researcher, Royal Irrigation Department from 1970 to 1981; the lecturer, School of Agriculture and Cooperatives, Sukothai Thammathirat Open University (1986-1988); assistant profressor, School of Agriculture and Coperatives, Sukothai Thammathirat Open University (1988-1998); associate professor School of Agriculture and Cooperatives, Sukothai Thammathirat Open
University (1999-2007); dean, Faculty of Technology and innovation, Bangkokthonburi University (2008-Present)

Assoc. Prof. Direk Tongaram has a memberships in Societies: Prof. Dr. Chidchanok Lursinsap, Prof. Dr. Jongjit Hirunlabh and Prof, Dr. Chaiyong Promwong. He has patent "Dynamic Root Floating Technique, DRFT) Patent number 095698 or 0402003233 on 25 Nov, 2004 and publisher 1.) Direk Tongaram. 1985. Potential evapotranspiration and crop coefficient for rice in Thailand. Irrigated Agriculture Branch. Operation and Maintenance Division. Royal Irrigation Department Ministry of Agriculture and Cooperatives. User Manual.

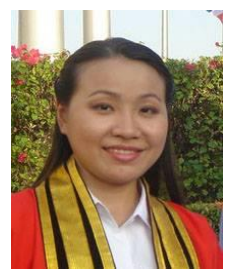

Nujcha Thatreenaranon was born in Thailand, in 1976. She got the B.S. Suan Dusit University, Bangkok, Thailand 1998; the M.I.Ed.(Muitimedia) King Mongkut's University Of Technology North Bangkok, Thailand 2002.

She worked as lecturer, Faculty of Science, Rajamangala University of Technology Rattanakosin (2003), lecturer, Faculty of Science and Technology (2004-Present).

Mrs. Nujcha Thatreenaranon has a memberships in Societies: Prof. Dr. Chidchanok Lursinsap, Prof. Dr. Jongjit Hirunlabh and Prof, Dr. Chaiyong Promwong. 